\title{
DEVELOPMENT OF SOIL PARAMETERS AND CHANGING LANDSCAPE STRUCTURE IN CONDITIONS OF COLD MOUNTAIN CLIMATE (CASE STUDY LIPTOVSKÁ TEPLIČKA)
}

\author{
DANICA FAZEKAŠOVÁ ${ }^{1}$, MARTIN BOLTIŽIAR ${ }^{2,5}$, LENKA BOBUL'SKÁ ${ }^{3}$, DANA \\ KOTOROVÁ ${ }^{4}$, JÁN HECL ${ }^{4}$, ZDENA KRNÁČOVÁ ${ }^{5}$
}

\footnotetext{
${ }^{1}$ University of Prešov, Faculty of Management, Department of Environmental Management, 081 16 Prešov, Ul. 17. Novembra č. 1, Slovak Republic; e-mail: danica.fazekasova@unipo.sk

${ }^{2}$ Constantine the Philosopher University in Nitra, Faculty of Natural Sciences, Department of Geography and Regional Development, Tr. A. Hlinku 1, 94901 Nitra, Slovak Republic; e-mail: mboltiziar@ukf.sk

${ }^{3}$ Institute of Biogeochemistry and Pollutant Dynamics, ETH Zürich, Environmental Microbiology, Switzerland; e-mail: bobulska.lenka@gmail.com

${ }^{4}$ Slovak Agricultural Research Centre - Agroecology Research Institute Michalovce, Špitálska 1273, 07101 Michalovce, Slovak Republic; e-mail: kotorova@minet.sk, hecl@minet.sk

${ }^{5}$ Institute of Landscape Ecology, Slovak Academy of Sciences, Akademická 2, 94901 Nitra, Slovak Republic; e-mail: zdena.krnacova@savba.sk
}

\begin{abstract}
Fazekašová D., Boltižiar M., Bobul'ská L., Kotorová D., Hecl J., Krnáčová Z.: Development of soil parameters and changing landscape structure in conditions of cold mountain climate (case study Liptovská Teplička). Ekológia (Bratislava), Vol. 32, No. 2, p. 197-210, 2013.

Soil physical, chemical and biological properties and the content of heavy metals were investigated between 1997 and 2010 and changing landscape structure was evaluated for years 1948-2010 under production conditions in the investigated area Liptovská Teplička $\left(48^{\circ} 57^{\prime} \mathrm{N} ; 20^{\circ} 05^{\prime} \mathrm{E}\right)$, situated in the marginal region of north-eastern Slovakia. Research showed that soil physical properties get adjusted after a long-term application of ecological farming system and the measured values were stabilised. High doses of organic fertilizers had positive effect on soil fertility, and thus indirectly on maintaining soil $\mathrm{pH}$, available nutrients content and accumulation of humus in soil. The values of soil enzymes activities changed minimally during the research period. At the same time, it was proven that increasing the content of soil organic matter promotes natural protection of soil enzymes. This study underscores the importance of long-term, quantitative soil monitoring in determining the changes in agricultural land and ecosystem processes over time. Statistically significant effect of experimental year on all observed soil parameters was confirmed by analysis of variance. Effect of experimental locality, with the exception of $\mathrm{pH} / \mathrm{CaCl}_{2}, \mathrm{C}_{\text {ox }}$ and $\mathrm{N}_{\text {anorg }}$, on other soil parameters was also statistically significant. This area represents a specific mountain grassland-arable landscape with conservation of traditional agriculture. The results of this paper also analyse landscape structure changes by using the historical maps and aerial photographs of the past 160 years.
\end{abstract}

Key words: ecological farming system, chemical properties, physical properties, soil enzymes, heavy metals, landscape structure changes. 


\section{Introduction}

Agricultural activities are realised in landscape and affect natural resources. A rational usage of renewable and non-renewable resources which are not retrieved in real time is an essential precondition. The farming system is the most widespread environmental technology with its positive and negative consequences. It utilises essential natural resources and, at the same time, influences other natural environments. Soil parameters indicate the state of soil ecosystem characteristics, which especially reflect production, buffering, filter and other soil functions. From this view, the structure of soil profile (the soil class), soil type, soil depth, skeletal nature, the content and quality of humus substances, accessible nutrient supply, soil reaction, the content of foreign substances in soil and soil edaphon seem to be of highest importance. Maintenance of the environmental quality and not exceeding the pollution limits are the most important indicators. Soil quality is significantly affected by the physical, chemical, biological and biochemical properties that are sensitive to changes in environment and soil management. Pollution of the soil environment with heavy metals negatively influences the whole ecosystem. The soil parameters such as $\mathrm{pH}$, organic matter, nitrogen content, nutrients availability, texture, bulk density, porosity and soil enzyme activities can influence the behaviour of metals in soil (Fazekašová, 2012; Beesley et al., 2010). Ecological stress and other environmental changes in soil ecosystem can be judged in advance through some sensitive and warning indicators. These indicators include biological and biochemical properties in soil, including microbial quotient, nitrogen mineralization and the activities of soil enzymes (Nannipieri et al., 2003; Sarkar et al., 2009).

This area is a specific mountain grassland-arable landscape with conservation of traditional agriculture. Historical structures of this area represent extensive cultivated fields, meadows and pastures, which have not been affected by agriculture collectivization and are characteristic by the following features: small-scale structure of the plot and original forms of anthropogenic relief. It is from this point of view that we have also focused to analyse the influences to this unique landscape structure changes by using the historical maps and aerial photographs of the past 160 years.

The paper presents the results of long-term monitoring and impact assessment of ecological farming system on selected soil parameter developments and changing of landscape structure in less favourable soil-climatic conditions.

\section{Material and methods}

The research project was carried out during the years 1997-2000 and 2008-2010 under production conditions in the investigated area Liptovská Teplička $\left(48^{\circ} 57^{\prime} \mathrm{N} ; 20^{\circ} 05^{\prime} \mathrm{E}\right)$, situated in the marginal region of north-eastern Slovakia. The ecological farming system has been applied here since 1996 (Hanzes et al., 2006, 2011).

The area of Liptovská Teplička is situated in the Low Tatras National Park at an altitude ranging from 846 to $1492 \mathrm{~m}$ a.s.l. In terms of geomorphological division, it is a part of the sub-assemblies of the Královohol'ské Mountains (Michaeli, Ivanová, 2005). The whole area is situated in the mild zone with sum of average daily temperatures above $10^{\circ} \mathrm{C}$ ranging from 1600 to $2000 \mathrm{~mm}$ and average precipitation of $700-1200 \mathrm{~mm}$ (Fig. 1).

In the current crop structure, cereal acreage represents $33.3 \%$, potatoes $16-18 \%$ and fodder crops $49.8 \%$. Crop rotation is as follows: perennial fodder (clover mixture), winter crops (winter wheat, winter rye, triticale and winter barley), root crops (potatoes), spring crops (spring barley, oats) and annual mixture (oats pea, peas, ryegrass). Arable land is fertilized with manure dosage of about $30 \mathrm{t} \mathrm{ha}^{-1}$ once in two years (Fazekašová et al., 2011, 2012). 


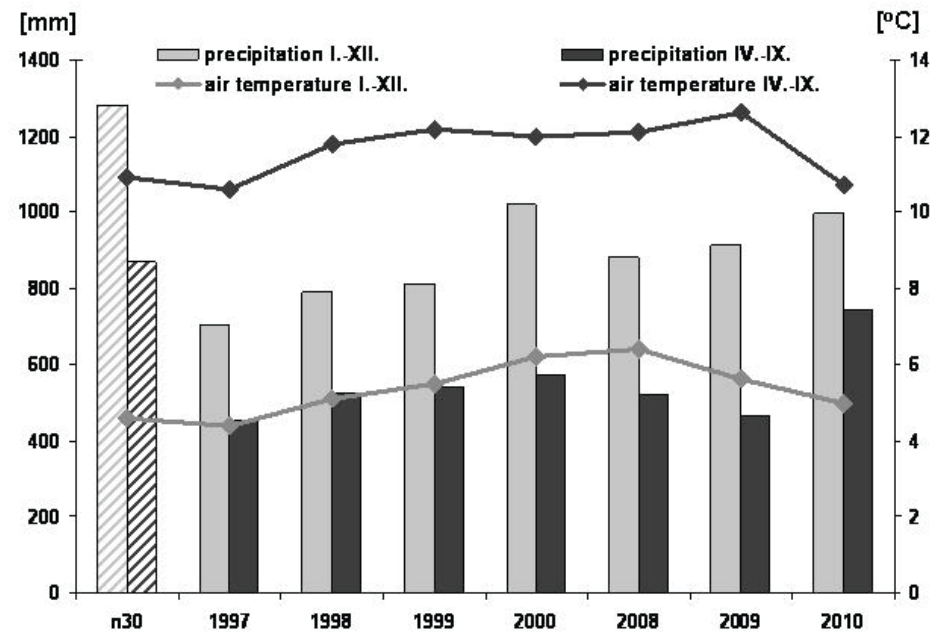

Fig. 1. The course of average air temperatures $\left({ }^{\circ} \mathrm{C}\right)$ and sum of precipitation $(\mathrm{mm})$ during observed period $(\mathrm{n} 30=$ long time normal).

Soil samples for physical, chemical and biological properties and heavy metals content determination were sampled in spring time in connected stand on five permanent research sites. Soil bulk density and soil porosity were studied and evaluated as the general physical properties in Kopecky physical cylinder with a capacity of 100 $\mathrm{cm}^{3}$ (Fiala et al., 1999). From the chemical soil characteristics, we monitored and evaluated soil $\mathrm{pH}$ in $1 \mathrm{M} \mathrm{CaCl}_{2}$ solution an organic nitrogen, available phosphorus, potassium and magnesium with Mehlich III and organic carbon content (Fiala et al., 1999). Available heavy metal content (Cd, Ni and $\mathrm{Pb}$ ) in the soil samples were determinated in $2 \mathrm{M} \mathrm{HNO}_{3}$ solution using atomic absorption spectrophotometer (Matúšková, Vojtáš, 2005). Monitored biological soil characteristics were as follows: activity of acid and alkaline phosphatase (Grejtovský, 1991) and urease (Chaziev, 1976).

For the analysis of landscape structure changes we used historical military maps at the scales of 1:28,886 (year 1826) and orthophotos from 1949 (panchromatic) and 2006 (real colors) were used as base layers. For the identification of landscape structure elements a modified legend was used. They were identified through manual vectorisation ('on screen' method) of historical maps and orthophotos by the GIS software - ArcGIS 10.2.

Obtained data were tested by mathematical-statistical methods from which analysis of variance and regression analysis were used (the Statgraphics software package).

\section{Results and discussion}

\section{Development of soil parameters}

The variety topography, mineral substrates and considerable humidity area necessitated the creation and development of a specific spectrum of soils. On carbonate minerals - dolomites and limestones - moderate to strong skeletal Rendzic Leptosols were created. In higher altitude and higher humidity they alter to Cambic Rendzic Leptosols. The occurrence of these minerals binds on south part of cadastral area of Liptovská Teplička on large complex of Ramsar dolomitic limestones. Mineral-rich, non-carbonate substrates such as basalts, an- 
desites and marl slate make the part of moderate humic and medium depth of Cambisols. These Cambisols can be found in northern part of territory. This Haplic Cambisols complex is used as small terraced fields near built-up area of Liptovská Teplička village. Poor mineral rocks such as light grey conglomerates, variegated sandstone, siltstones and slate make the formation Haplic and Stagnic Cambisols. Valleys bottoms are constructed by fluvial sediments where a complex of Haplic and Gleyic Fluvisols was developed.

Physical parameters are specific characteristics of soil and their change occurs in adjusting of ecological conditions of the crops grown. Favourable physical parameters of soil are now becoming targets to which the management and protection of land is looking forward. The basic physical parameters of the soil are bulk density and total soil porosity (Kotorová, Šoltysová, 2011). On the basis of clay particles content and in accordance with Novák's classification scale (Fulajtár, 2006; Zaujec et al., 2009), soils in monitored sites are loamy-sandy soils, loamy soils and clayey-loamy soils (Fazekašová et al., 2011).

Bulk density as an integral value of the soil grain, humus content and anthropogenic impacts on soil should not increase over limits given for individual types of soil (Table 1).

T a b le 1. Critical values of soil bulk density $\left(\mathrm{t} \mathrm{m}^{-3}\right)$ and porosity (\%) for different soil texture (Líška et al., 2008).

\begin{tabular}{|l|l|l|l|l|l|l|}
\hline Soil texture & Sandy & Loamy sand & Sandy loam & Loam & Clayey loam and clay & Clay \\
\hline Bulk density & $\geq 1.70$ & $\geq 1.60$ & $\geq 1.55$ & $\geq 1.45$ & $\geq 1.40$ & $\geq 1.35$ \\
\hline Porosity & $\leq 38$ & $\leq 40$ & $\leq 42$ & $\leq 45$ & $\leq 47$ & $\leq 48$ \\
\hline
\end{tabular}

Long-term research has shown that ecological soil farming regulates bulk density of soil. The measured values of bulk density were in the range of 0.94 to $1.35 \mathrm{t} \mathrm{m}^{-3}$ (Fig. 2). During 1997-2009, there was a moderate decrease and values comparable to average figures for the given soil type and category according to Líška et al. (2008) were achieved (Table 1); except in 2010, when a mild increase in bulk density was measured. At the same time, this parameter proved to change under the influence of the water content and meteorological exposure (Kotorová et al., 2010). In 2010, in comparison to the previous years, the precipitations reached higher values (Fig. 1). General porosity is closely related to bulk density. From the total pore volume, this should not fall below $38 \%$ for sandy soil and below $48 \%$ for clayey-loamy soil (Líška et al., 2008). As seen from Fig. 2, the values show that, in the observed time frame, porosity levels ranged between 46.43 and $64.49 \%$. Considering this parameter, optimum conditions were created for the growth of most arable crops, which are given by general porosity between 55 and $65 \%$ and 20 and 25\% soil air content (Rode, 1969).

Soil $\mathrm{pH}$ is one of the important factors of soil fertility despite the fact that its values change dynamically depending on so-called internal and external factors. Factors including parent material, weathering and current agricultural practices influenced the $\mathrm{pH}$ of a soil change over time. It affects the availability of nutrients and how the nutrients react with each other. During the monitoring period the value varied minimally, and the average value of soil reaction, expressed as $\mathrm{pH} / \mathrm{CaCl}_{2}$, ranged between 5.1 and 7.2 (Fig. 3). This can be assigned to the ecological farming system because the physiologically acid mineral fertilizers were not applied, and the organic fertilizers (manure at the dosage $30 \mathrm{t} \mathrm{ha}^{-1}$ and Natural Harmony at 

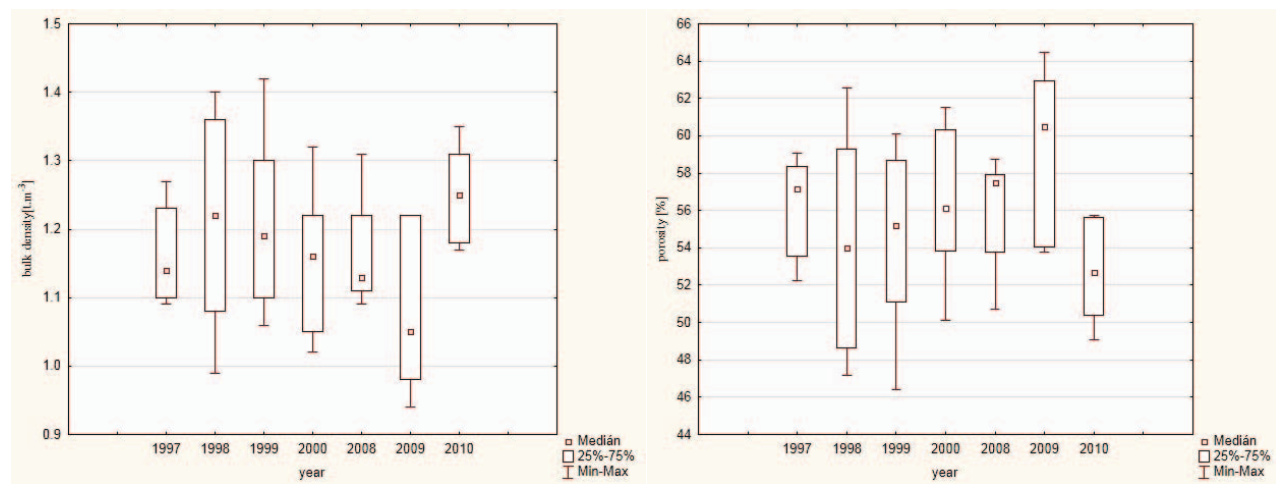

Fig. 2. Bulk density and porosity of soil on the studied area Liptovská Teplička in the years 1997-2010.

the dosage $3000 \mathrm{t} \mathrm{ha}^{-1}$ ) were applied. Organic matter positively influences the buffering capacity of soil and thus the soil reaction was not reduced.

Particular attention should be paid to the adjustment of soil reaction on soil where the $\mathrm{pH}$ is below 5.5, because of the release of aluminium ions and their toxic effects on plants. For most crops, the soil reaction ranges 6.5 and this value provides favourable conditions for root nutrition and microbial activity. Organic matter content affects to maintain soil reaction. Despite the positive impact of ecological farming system to maintain soil acidity and organic matter content, it is necessary to continuously pay attention to soil reaction as soil is naturally acidified through acid atmospheric fallout as well as calcium uptake by plants. $\mathrm{Hu}-$ mus content is a parameter that is liable to significant changes during longer periods of time. Application of high amounts of organic fertilizers had an effect on maintaining or slightly increasing humus content. The values of $\mathrm{C}_{\text {ox }}$ ranged from 2.16 to $3.92 \%$, which on conversion to humus (conversion coefficient 1.724) are medium and good humic soils (Vilček et al., 2005). Our research confirmed suitability of the area for ecological farming and at the same time the positive influence of the applied system on humus balance in soil. There is a little probability that increasing of the total nitrogen content has a positive effect on the soil fertility (Bielek, 1998). This applies only for productive and highly productive soils. For the soils with low production capacity, to which the investigated area belongs, a reciprocal relationship between total nitrogen content and soil fertility is typical. Total nitrogen content in soil, 95 to $98 \%$ is bound in organic forms, fertility functions are conditioned to mechanisms of its accessibility to plants. It is mainly organic nitrogen mineralization, more specifically the part of mineralization, which prevails over carbon immobilization that relates to fertility. In the soil-ecological conditions of the investigated area, the nitrogen mineralization is less intensive (optimal temperature for intensive process is $28-30^{\circ} \mathrm{C}$ ), therefore, the content of mineral, that is immediately available nitrogen, may not be high even at high levels of total nitrogen (Fig. 3). The assumption is that addition of high doses of organic fertilizer will increase the total nitrogen content, but growing legumes included in the crop rotation can increase the content of immediately available nitrogen. Phosphorus is firmly fixed in soil and its proportion is relatively stable and dependent on soil reaction values. The value of soil $\mathrm{pH}$ 
did not change significantly in the investigated area between 1997-2000 and 2008-2010, and the proportion of available phosphorus changed only minimally (Fig. 3). The proportion of potassium and magnesium was relatively stable during the research period (Fig. 3). Due to the grain structure of the soils (medium and heavy soils) these nutrients are bound to the soil particles and are not liable to soil washing in spite of high precipitation throughout the year.
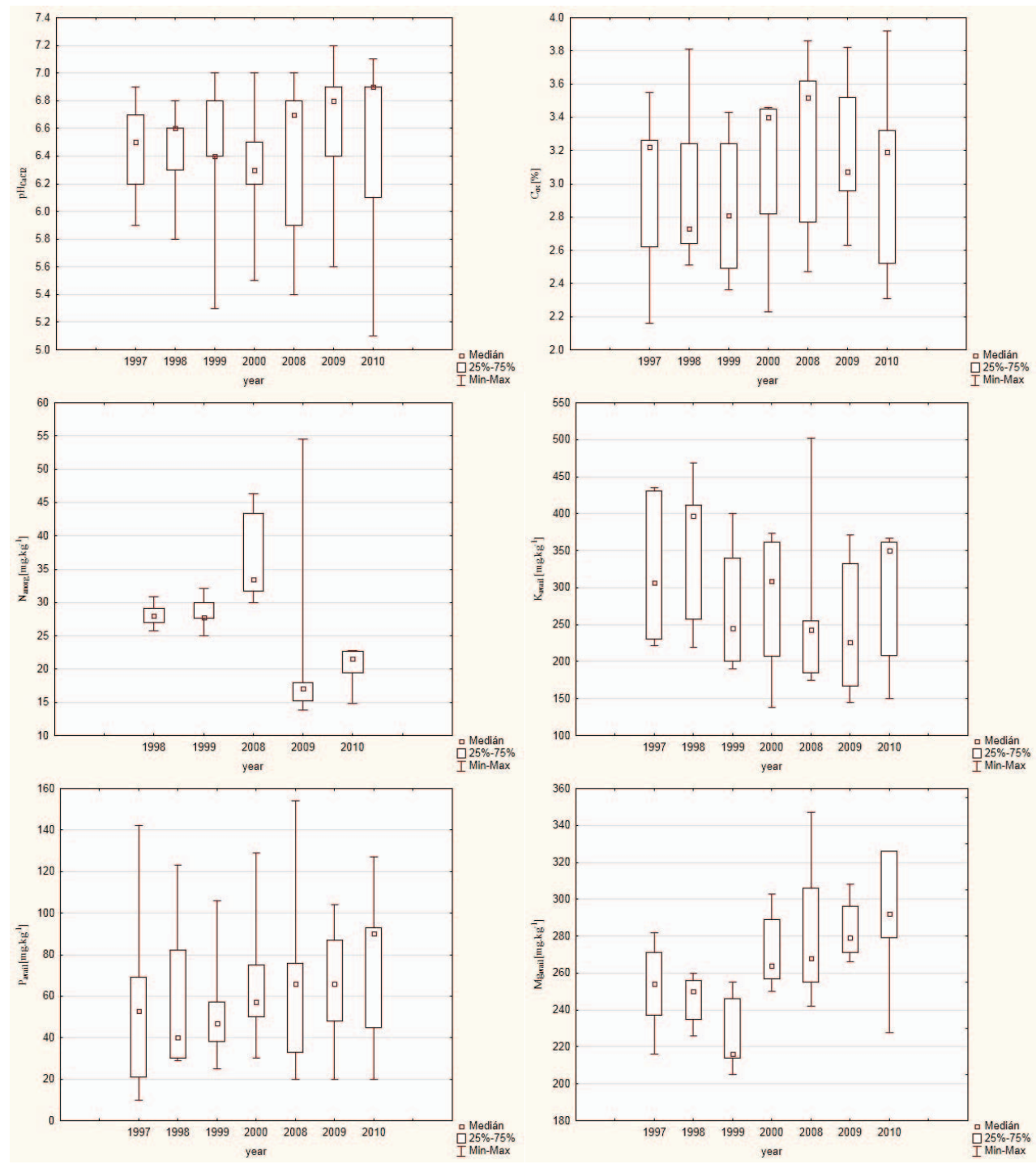

Fig. 3.Soil chemical parameters $\left(\mathrm{pH}, \mathrm{C}_{\mathrm{ox}}, \mathrm{N}_{\text {anorg, }} \mathrm{K}_{\text {avail, }} \mathrm{P}_{\text {avail }}, \mathrm{Mg}_{\text {avail }}\right)$ on the studied area Liptovská Teplička in the years $1997-2010$. 
Soil enzymes regulate the functioning of the ecosystem and play key biochemical functions in the overall process of organic matter decomposition in the soil system (Burns, 1983; Sinsabaugh et al., 1997). They are important in catalysing several important reactions necessary for the life processes of micro-organisms in soils and the stabilisation of soil structure, the decomposition of organic wastes, organic matter formation and nutrient cycling (Dick et al., 1994). There was minimum fluctuation in the measured values of soil enzyme activity in the observed period. The urease values ranged from 0.43 to $0.67 \mathrm{mg} \mathrm{NH} 4^{+}-\mathrm{N}^{-\mathrm{g}^{-1}} \cdot 24 \mathrm{~h}^{-1}$, and the values of acidic and alkaline phosphatise between 236.8 and $336.5 \mu \mathrm{g} \mathrm{P.g}{ }^{-1} .3 \mathrm{~h}^{-1}$ (Fig. 4). These are values typical for sparse-vegetation soils (Burns, 1978). At the same time, a higher activity of soil enzymes in lower temperatures was confirmed (the area is situated in a mild district with a sum of average daily temperatures above $10^{\circ} \mathrm{C}$, ranging from 1600 to 2000 , and average precipitation between 700 and $1200 \mathrm{~mm}$ ) and organic fertilisers and soil organic mass stimulate the activity of soil phosphatise and significantly enhance the protection of natural soil urease (Chaziev, 1976; Burns, 1978).
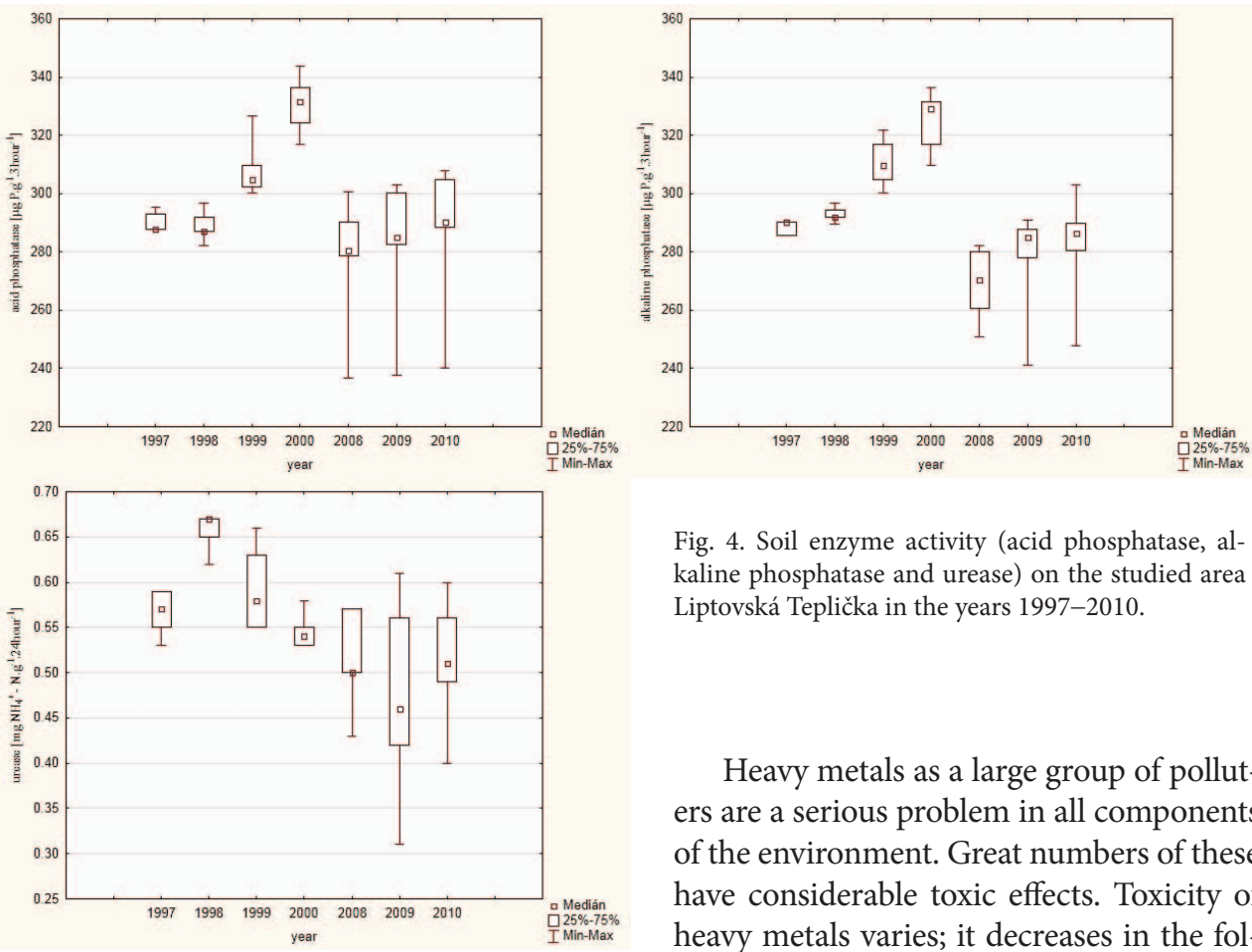

Fig. 4. Soil enzyme activity (acid phosphatase, alkaline phosphatase and urease) on the studied area Liptovská Teplička in the years 1997-2010.

Heavy metals as a large group of polluters are a serious problem in all components of the environment. Great numbers of these have considerable toxic effects. Toxicity of heavy metals varies; it decreases in the following order $\mathrm{Hg}>\mathrm{Cd}>\mathrm{Ni}>\mathrm{Pb}>\mathrm{Cr}$ and their influence is enhanced by their non-degradability. Soil is only presented as a passive acceptor of heavy metals; it becomes the source of polluting other components of the environment and the food chain. Changes in soil properties are responsible for the mobilisation of metals, espe- 
cially $\mathrm{pH}$, humus content and quality and the proportion of clay fraction (Barančíková, 1998). With regards to the above findings, the content of the following risk elements was observed in the conditions of sustainable use of soil: lead, cadmium and nickel (in the leachate $2 \mathrm{M} \mathrm{HNO}_{3}$ ) (Fig. 5). The evaluation showed that the content of dangerous elements in soil did not reach maximum permitted values for the Slovak Republic (Act No. 220/2004 Coll.) and the measured values corresponded with natural contents of the observed elements in soil and base rocks (Makovníková et al., 2006). At the same time, in ecological systems, no anthropogenic pollution by applying chemical substances and sediments in soil is present.
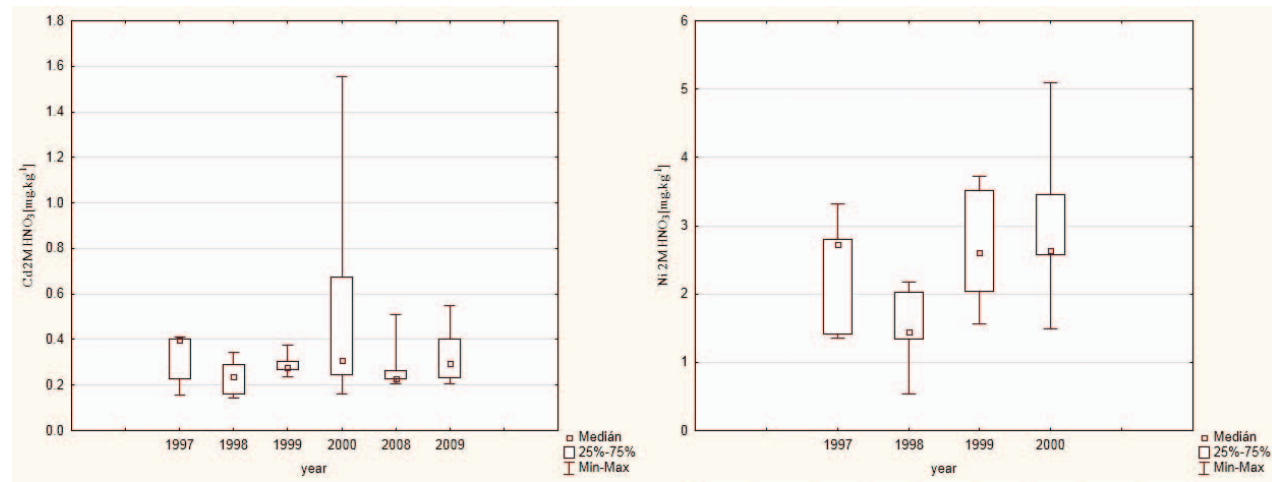

Fig. 5. Heavy metals content (lead, cadmium and nickel) on the studied area Liptovská Teplička in the years 1997-2009.

Statistically significant effect of experimental year on all observed soil parameters was confirmed by analysis of variance (Table 2). Effect of experimental locality, with the exception of $\mathrm{pH} / \mathrm{CaCl}_{2}, \mathrm{C}_{\text {ox }}$ and $\mathrm{N}_{\text {anorg }}$, on other soil parameters was also statistically significant. Significant, statistical and statistically sig-

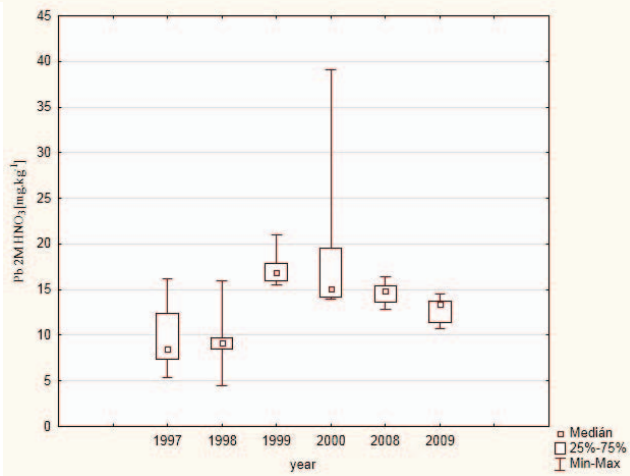
nificant dependences between observed soil parameters are expressed in Table 3.

\section{Landscape structure changes in the selected time horizons}

Landscape structure changes were identified from historical military maps (1846) and historical and present aerial orthophotographs (years 1949 and 2010 processed in GIS. This approach is a typical standard method in this specific research (Olah, 2003a, b, 2009; Pucherová, 2004; Faltan, Bánovský, 2008; Faltan et al., 2009, 2011; Šolcová, 2012; Vojteková, 2013; Ivanová, 2013; Solár, 2012) Specific landscape structure of the study area represented the relatively stable territory with these following significant changes: 
T a b l e 2. Variance analyses of physical, chemical and biological parameters.

\begin{tabular}{|c|c|c|c|c|c|c|c|c|c|}
\hline Parameter & Min. & Max. & Mean & $\begin{array}{c}\text { Standard } \\
\text { error }\end{array}$ & $\begin{array}{l}\text { P signi- } \\
\text { ficance }\end{array}$ & $\begin{array}{l}\text { Source } \\
\text { of vari- } \\
\text { ability }\end{array}$ & d. f. & F-Ratio & $\mathbf{P}$ \\
\hline \multirow{2}{*}{ bulk density $\left(\mathrm{t} . \mathrm{m}^{-3}\right)$} & \multirow{2}{*}{1.04} & \multirow{2}{*}{1.35} & \multirow{2}{*}{1.18} & \multirow{2}{*}{0.016347} & \multirow{2}{*}{++} & year & 6 & 8.33 & ++ \\
\hline & & & & & & locality & 4 & 28.39 & ++ \\
\hline \multirow{2}{*}{ porosity (\%) } & \multirow{2}{*}{49.15} & \multirow{2}{*}{60.56} & \multirow{2}{*}{55.52} & \multirow{2}{*}{0.617864} & \multirow{2}{*}{++} & year & 6 & 8.24 & ++ \\
\hline & & & & & & locality & 4 & 28.41 & ++ \\
\hline \multirow{2}{*}{$\mathrm{pH} / \mathrm{CaCl}_{2}$} & \multirow{2}{*}{5.77} & \multirow{2}{*}{7.13} & \multirow{2}{*}{6.41} & \multirow{2}{*}{0.083124} & \multirow[b]{2}{*}{-} & year & 6 & 0.82 & - \\
\hline & & & & & & locality & 4 & 24.51 & ++ \\
\hline \multirow{2}{*}{$\mathrm{C}_{\mathrm{ox}}(\%)$} & \multirow{2}{*}{2.25} & \multirow{2}{*}{3.61} & \multirow{2}{*}{3.03} & \multirow{2}{*}{0.084802} & \multirow[b]{2}{*}{-} & year & 6 & 1.46 & - \\
\hline & & & & & & locality & 4 & 23.99 & ++ \\
\hline \multirow{2}{*}{$\mathrm{N}_{\text {anorg }}\left(\mathrm{mg} \cdot \mathrm{kg}^{-1}\right)$} & \multirow{2}{*}{16.76} & \multirow{2}{*}{40.50} & \multirow{2}{*}{27.52} & \multirow{2}{*}{1.698623} & \multirow{2}{*}{++} & year & 6 & 12.77 & ++ \\
\hline & & & & & & locality & 4 & 2.22 & - \\
\hline & 1997 & 12788 & 6463 & 3494827 & & year & 6 & 3.02 & ++ \\
\hline$P_{\text {avai }}\left(\mathrm{mg} . \mathrm{kg}^{2}\right)$ & 19.91 & $12 / .88$ & 04.63 & 3.494827 & ++ & locality & 4 & 121.06 & ++ \\
\hline & & & & & & year & 6 & 5.87 & ++ \\
\hline $\mathrm{K}_{\text {avail }}\left(\mathrm{mg} \cdot \mathrm{kg}^{-1}\right)$ & 168.59 & 427.98 & 290.91 & 12.5772 & ++ & locality & 4 & 43.46 & ++ \\
\hline & & & & & & year & 6 & 17.52 & ++ \\
\hline $\mathrm{M}_{\text {gavail }}\left(\mathrm{mg} \cdot \mathrm{kg}^{-1}\right)$ & 215.98 & 301.43 & 265.0 & 4.918103 & ++ & locality & 4 & 3.73 & ++ \\
\hline & 777 & 2218 & 1411 & 0823555 & & year & 6 & 12.30 & ++ \\
\hline PDZMHNO 3 (mg.kg $)$ & 7.77 & 22.18 & 14.11 & 0.823555 & ++ & locality & 4 & 22.01 & ++ \\
\hline $\mathrm{Cd} 2 \mathrm{M} \mathrm{HNO}_{3}$ & $012 x+8$ & 60 & 21 & & & year & 6 & 9.37 & ++ \\
\hline$\left(\mathrm{mg} \cdot \mathrm{kg}^{-1}\right)$ & 0.129 & 0.697 & 0.343 & $0.03 / 233$ & ++ & locality & 4 & 19.69 & ++ \\
\hline $\mathrm{Ni} 2 \mathrm{M} \mathrm{HNO}_{3}$ & 0934 & 3436 & 2392 & 0140375 & $+t$ & year & 6 & 24.08 & ++ \\
\hline$\left(\mathrm{mg} \cdot \mathrm{kg}^{-1}\right)$ & 0.504 & 5.400 & 2.092 & 0.140373 & TT & locality & 4 & 25.20 & ++ \\
\hline urease $\left(\mathrm{mg} \mathrm{NH}_{4}^{+}\right.$- & & & & & & year & 6 & 44.07 & ++ \\
\hline N.g ${ }^{-1} \cdot 24$ hour $\left.^{-1}\right)^{4}$ & 0.454 & 0.674 & 551 & 0.007954 & ++ & locality & 4 & 33.12 & ++ \\
\hline acid phosphatase & 271.23 & 30677 & 29491 & 265001 & t+ & year & 6 & 36.16 & ++ \\
\hline$\left(\mu \mathrm{g} \mathrm{P.g}^{-1} \cdot 3\right.$ hour $\left.^{-1}\right)$ & $2 / 1.23$ & 300.17 & 294.91 & 2.05001 & ++ & locality & 4 & 15.85 & ++ \\
\hline alkaline phosphatase & 26435 & 32933 & 29197 & & & year & 6 & 75.50 & ++ \\
\hline$\left(\mu \mathrm{g}\right.$ P.g $^{-1} .3$ hour $\left.^{-1}\right)$ & 264.35 & 329.33 & 291.91 & $1.9656 /$ & ++ & locality & 4 & 16.39 & ++ \\
\hline
\end{tabular}

$++\mathrm{P}<0.01+\mathrm{P}<0.05$

\section{Landscape structure in 1846}

The village Liptovská Teplička on the northern slopes of the Nízke Tatry Mountains significantly determines the historical land use. The dominant element of the landscape in 1846 was the forest cover stretched to across the land area and accounted for more than 7541 ha $(76.54 \%$ of the total account.). Outside the forest are clearly identified permanent grasslands and small arable land. Permanent grasslands were located in the central part of the land and along streams. Meadow vegetation were more than 1238 ha (12.57\% land) and pastures around 360 ha (3.65\%). Arable land located in a floodplain Čierny Váh area represented 566 ha (5.75\%). 


\begin{tabular}{|c|c|c|c|c|c|c|c|c|c|c|c|c|c|c|c|}
\hline 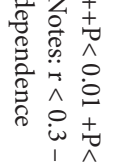 & 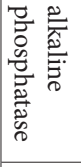 & 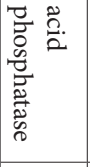 & $\begin{array}{l}E \\
\text { E } \\
\text { हैं } \\
0\end{array}$ & $Z$ & $\curvearrowright$ & $\ddot{\sigma}$ & 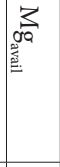 & 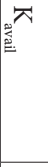 & 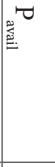 & 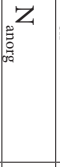 & $\approx$ & 胥 & $\begin{array}{l}\text { T. } \\
0 \\
0 \\
0 \\
y \\
y\end{array}$ & 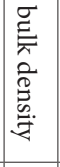 & 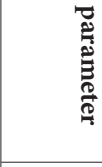 \\
\hline 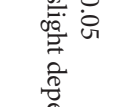 & 它 & $\begin{array}{l}\dot{b} \\
\dot{0} \\
\text { on }\end{array}$ & $\begin{array}{l}1 \\
0 \\
0 \\
\infty \\
\infty \\
\infty\end{array}$ & $\begin{array}{l}\dot{0} \\
\dot{0} \\
\dot{1}\end{array}$ & \begin{tabular}{l}
1 \\
0 \\
0 \\
1 \\
\multirow{1}{*}{}
\end{tabular} & $\begin{array}{l}1 \\
0 \\
0 \\
\infty\end{array}$ & $\begin{array}{l}1 \\
\dot{0} \\
\dot{\alpha} \\
\dot{\omega}\end{array}$ & 它 & $\begin{array}{l}\dot{0} \\
\dot{3} \\
\dot{1}\end{array}$ & 总 & $\begin{array}{l}\dot{1} \\
\dot{n} \\
\underline{E} \\
+ \\
+\end{array}$ & 它 & \begin{tabular}{|l|}
1 \\
$\dot{j}$ \\
0 \\
0 \\
+ \\
+ \\
\end{tabular} & & 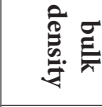 \\
\hline $\begin{array}{l}\stackrel{0}{0} \\
\stackrel{0}{0} \\
\stackrel{0}{0}\end{array}$ & 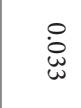 & $\begin{array}{l}\stackrel{0}{0} \\
\dot{W} \\
\text { and }\end{array}$ & $\begin{array}{l}0 \\
\dot{0} \\
\dot{0}\end{array}$ & $\begin{array}{l}\stackrel{0}{0} \\
\stackrel{0}{\mathrm{G}}\end{array}$ & 号 & 웅 & 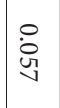 & 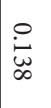 & 总 & 远 & 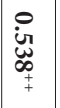 & 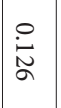 & & $\begin{array}{l}1 \\
\dot{0} \\
\dot{0} \\
0 \\
0 \\
+\end{array}$ & 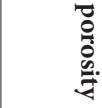 \\
\hline $\begin{array}{l}0 \\
\text { in } \\
1 \\
8 \\
0 \\
0 \\
0\end{array}$ & 官 & $\underset{\dot{\tilde{S}}}{\stackrel{i}{v}}$ & 总 & 怘 & 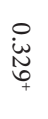 & $\begin{array}{l}1 \\
0 \\
0 \\
1 \\
\infty\end{array}$ & 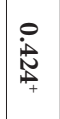 & 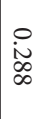 & 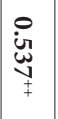 & $\begin{array}{l}\dot{0} \\
\text { 点 }\end{array}$ & 运 & & $\stackrel{0}{\stackrel{0}{N}}$ & $\begin{array}{l}\dot{b} \\
\stackrel{2}{\text { N }}\end{array}$ & مُ \\
\hline 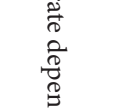 & 怘 & $\begin{array}{l}\dot{0} \\
\dot{\infty} \\
\stackrel{\circ}{a}\end{array}$ & $\begin{array}{l}\stackrel{\circ}{\vec{g}} \\
\sigma\end{array}$ & 总 & 总 & $\begin{array}{l}\dot{0} \\
\dot{8} \\
\dot{1}\end{array}$ & $\begin{array}{l}\dot{\tilde{N}} \\
\stackrel{\Omega}{\Xi}\end{array}$ & 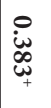 & 嶽 & 兽 & & 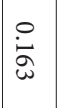 & $\begin{array}{c}\underset{:}{i} \\
\underset{\infty}{W} \\
\infty \\
+ \\
+\end{array}$ & 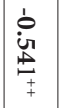 & ${ }_{2} \Omega$ \\
\hline 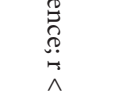 & ஷ் & : & 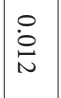 & & 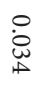 & ㅇ. & $\stackrel{\dot{0}}{\dot{\Xi}}$ & $\stackrel{\circ}{\ddots}$ & $\dot{0}$ & & 迸 & 它 & $\begin{array}{l}\dot{1} \\
\dot{N} \\
\text { N }\end{array}$ & $\begin{array}{l}0 \\
\dot{D} \\
\tilde{n} \\
\text { U. }\end{array}$ & 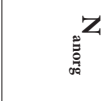 \\
\hline 点. & 定 & $\stackrel{d}{\omega}_{\omega}^{d}$ & $\begin{array}{l}0 \\
i \\
\text { U } \\
\mathcal{V}\end{array}$ & 递 & $\begin{array}{l}0 \\
\substack{\infty \\
\infty \\
\infty \\
+\\
+}\end{array}$ & 怘 & $\begin{array}{l}0 \\
\dot{\omega} \\
\text { o } \\
+\end{array}$ & 唄 & & 它 & 家 & 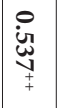 & $\begin{array}{l}\text { 苛 } \\
\text { 志 }\end{array}$ & $\begin{array}{l}\dot{b} \\
\dot{4} \\
\text { 出 }\end{array}$ & 包 \\
\hline 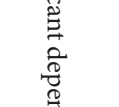 & $\begin{array}{l}\dot{1} \\
\dot{0} \\
0 \\
0\end{array}$ & 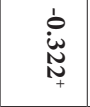 & $\begin{array}{l}0 \\
\underset{\sim}{W} \\
\infty \\
+\end{array}$ & $\begin{array}{l}\dot{j} \\
\dot{\omega} \\
\infty \\
\omega \\
+\end{array}$ & 离 & 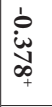 & $\begin{array}{l}0 \\
\dot{0} \\
\infty \\
+\end{array}$ & & 版 & 움 & 宓 & $\begin{array}{l}\underset{\sim}{\infty} \\
\infty \\
\infty \\
\infty\end{array}$ & 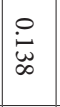 & 方 & $\stackrel{n}{e}^{\pi}$ \\
\hline $\begin{array}{l}\stackrel{\overrightarrow{0}}{0} \\
\stackrel{\leftrightarrow}{\leftrightarrow} \\
\wedge\end{array}$ & 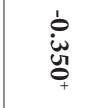 & $\begin{array}{l}\dot{i} \\
\underset{\infty}{\infty} \\
\stackrel{\infty}{*}\end{array}$ & $\begin{array}{l}\dot{1} \\
i \\
i \infty \\
i \\
i\end{array}$ & 总 & $\begin{array}{l}0 \\
\dot{0} \\
\dot{0} \\
\text { w }\end{array}$ & $\begin{array}{l}1 \\
0 \\
\text { 总 } \\
+ \\
+\end{array}$ & & $\begin{array}{l}0 \\
\dot{\infty} \\
\infty\end{array}$ & 岕 & $\underset{\infty}{\dot{\infty}}$ & $\begin{array}{l}\stackrel{0}{\tilde{\sigma}} \\
\stackrel{\Omega}{\sigma}\end{array}$ & $\begin{array}{l}\stackrel{0}{0} \\
\stackrel{i}{N} \\
\stackrel{+}{+}\end{array}$ & : & 亥 & 蛋 \\
\hline$\vec{D}$ & 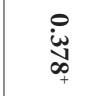 & $\underset{+}{\stackrel{\infty}{+}}$ & 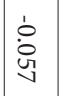 & 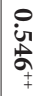 & $\underset{\substack{\text { i } \\
\infty}}{\stackrel{0}{*}}$ & & 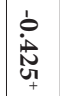 & 它 & 总 & : & $\dot{8}$ & $\begin{array}{l}\dot{1} \\
\dot{0} \\
\dot{\infty}\end{array}$ & $\stackrel{\stackrel{0}{5}}{\mathrm{~s}}$ & $\begin{array}{l}\dot{b} \\
\dot{0} \\
\infty \\
\infty\end{array}$ & " \\
\hline $\begin{array}{l}\frac{\hat{\Omega}}{2} \\
\frac{8}{8}\end{array}$ & 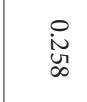 & $\begin{array}{l}\stackrel{i}{N} \\
\text { N }\end{array}$ & $\begin{array}{l}\dot{0} \\
\dot{0} \\
\dot{\omega} \\
0\end{array}$ & $\mid \begin{array}{c}0 \\
\dot{y} \\
\infty \\
+\infty \\
+\end{array}$ & & 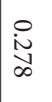 & $\begin{array}{l}0 \\
\dot{0} \\
0 \\
0\end{array}$ & $\stackrel{\text { O }}{\stackrel{\text { N }}{\mathrm{N}}}$ & $\begin{array}{l}0 \\
\dot{1} \\
\infty \\
\infty \\
+ \\
+\end{array}$ & $\begin{array}{l}0 \\
\dot{\omega} \\
w \\
⺊\end{array}$ & 总 & 总 & $\begin{array}{l}0 \\
\text { 足 } \\
\text { 志 }\end{array}$ & $\begin{array}{l}1 \\
\dot{0} \\
\dot{8} \\
\dot{1}\end{array}$ & 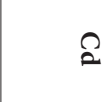 \\
\hline 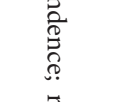 & 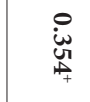 & 苦 & $\begin{array}{l}\dot{0} \\
\dot{i} \\
\dot{\omega}\end{array}$ & & 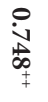 & 号 & 莣 & $\begin{array}{l}\dot{b} \\
\dot{\omega} \\
\infty \\
\dot{\infty} \\
+\end{array}$ & 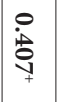 & : & 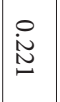 & 总 & 号 & $\begin{array}{l}\dot{1} \\
\dot{0} \\
\dot{0} \\
1\end{array}$ & $z$ \\
\hline 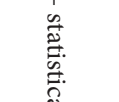 & $\underset{\text { 岕 }}{\stackrel{0}{u}}$ & $\begin{array}{l}\circ \\
\stackrel{0}{0} \\
\text { ă }\end{array}$ & & $\begin{array}{l}\dot{0} \\
\dot{\tilde{N}} \\
\mathbf{\omega}\end{array}$ & $\begin{array}{l}\dot{1} \\
\dot{0} \\
\dot{\omega} \\
0\end{array}$ & $\begin{array}{l}\dot{1} \\
\dot{0} \\
\dot{u} \\
\text { v }\end{array}$ & $\begin{array}{l}\dot{D} \\
\dot{\infty} \\
\dot{\infty} \\
ن\end{array}$ & 总 & ن & 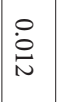 & 음 & 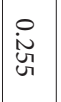 & $\begin{array}{l}0 \\
\dot{8} \\
0 \\
0\end{array}$ & $\begin{array}{l}1 \\
\dot{0} \\
\dot{0} \\
\infty\end{array}$ & 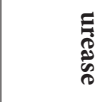 \\
\hline 点. & 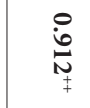 & & $\begin{array}{l}\stackrel{\circ}{\dot{O}} \\
\dot{\partial} \\
\sigma\end{array}$ & 菅 & 总 & 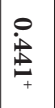 & $\begin{array}{l}\dot{D} \\
\dot{\infty} \\
\dot{\infty}\end{array}$ & 宓 & $\stackrel{\dot{b}}{\dot{\omega}}$ & $\stackrel{\circ}{\dot{\sigma}}$ & $\begin{array}{l}\stackrel{\circ}{0} \\
\dot{\circ}\end{array}$ & 怱 & 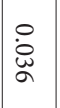 & $\begin{array}{l}\dot{0} \\
\dot{0} \\
\text { oू }\end{array}$ & 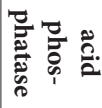 \\
\hline & & 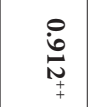 & 足 & 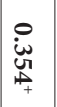 & $\begin{array}{l}0 \\
\stackrel{N}{U} \\
\infty\end{array}$ & 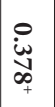 & $\begin{array}{l}\dot{0} \\
\dot{\infty} \\
\infty\end{array}$ & $\begin{array}{l}1 \\
0 \\
0 \\
0\end{array}$ & 它 & 영 & O & $\begin{array}{l}\dot{d} \\
\dot{\dot{a}} \\
\dot{1}\end{array}$ & 总 & $\begin{array}{l}\dot{0} \\
\dot{0} \\
\dot{U} \\
N\end{array}$ & 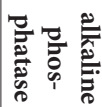 \\
\hline
\end{tabular}


The dominant group of land use in 1949 were still elements of the forest and seminatural areas. Overall, occupying more than 7500 ha, this was $76.14 \%$ of the cadaster. Second largest group of landscape elements were elements of agricultural land. Overall occupying an area of 2265 ha, this was $23 \%$ of the municipal area. The main elements in this region are different types and forms of permanent grassland. The largest element this group have been extensively used meadows along streams, but especially in the central part in the following locations: Doštianky, Grapy, Palenička, Okrúhle, Smrečina, Zálom, Hola and Vysoké a Kobyliarky, covered area 1088 ha (11.05\%). Arable land area was 522 ha $(5.3 \%)$.

\section{Landscape structure in 2010}

Changes in the management of the agricultural land in Liptovská Teplička occurred mainly in 1975 after collectivisation. The majority of the arable land was abandoned, part of the cultivated agricultural cooperative and the smaller part an individual as small fields. After succession arable land is now used these lands as extensive meadows and pastures with preserved between. Overview of land use change in the PPF in 1949 and now is presented in Table 4 . Forests now occupy $83.56 \%$ of the around land. The present species compositions of forests are mainly pine monocultures, which have been planted in place of the original mixed fir-beech forest.

\section{Conclusion}

Soil physical properties change not only under the influence of weather conditions, crop year and vegetation pass, but also under the influence of applied management system. During the year and growing season bulk density value also varies depending on water availability in the soil, weather and farming methods. Research showed that soil physical properties get adjusted after a long-term application of ecological farming system and the measured values were stabilised, reaching the levels comparable with the average values for the soil type. Agrochemical soil characteristics did not change significantly during the research period. High doses of organic fertilizers had positive effect on soil fertility and thus indirectly on maintaining soil $\mathrm{pH}$, available nutrients content and retention of humus in soil. Despite this, it is necessary to continuously pay attention to soil reaction as soil is naturally acidified through acid atmospheric fallout as well as calcium uptake by plants. Values of selected heavy metals in the monitored period did not exceed the limit values published in Act No. 220/2004 Coll.

The values of activity of phosphatases and ureases changed minimally during the research period and they refer to the values typical for soils with sparse vegetation. At the same time, it was proven that increasing the content of soil organic matter promotes natural protection of soil enzymes. The analysis of variance confirmed statistically significant effect of experimental year on all observed soil parameters. Effect of experimen- 
T a b le 4. Representation of elements of agricultural landscape structure form in years 1949 and 2010 (Špulerová et al., 2011).

\begin{tabular}{|c|c|c|c|c|}
\hline \multirow{2}{*}{$\begin{array}{l}\text { The elements secondary of } \\
\text { landscape structure } \\
\text { (code legend) }\end{array}$} & \multicolumn{2}{|c|}{$\begin{array}{l}\text { The historic landscape structure } \\
\text { (1949) }\end{array}$} & \multicolumn{2}{|c|}{$\begin{array}{l}\text { The present landscape structure } \\
(2010)\end{array}$} \\
\hline & area (ha) & area $(\%)$ & area (ha) & area $(\%)$ \\
\hline \multicolumn{5}{|l|}{ Agricultural area } \\
\hline $\begin{array}{l}\text { Large arable land with the presence } \\
\text { of non-forest woody vegetation } \\
\text { (NDV) to } 10 \% \text { (2111) }\end{array}$ & & & 54.00 & 0.55 \\
\hline Small arable land (2112) & 522.75 & 5.31 & 4.96 & 0.05 \\
\hline Intensively used meadows (23111) & & & 196.75 & 2.00 \\
\hline Extensively used meadows (23112) & 1088.85 & 11.05 & 276.75 & 2.81 \\
\hline $\begin{array}{l}\text { Abandoned meadows (degree } \\
\text { overgrowing NDV to } 40 \%)(23113)\end{array}$ & 2.10 & 0.02 & 36.48 & 0.37 \\
\hline Intensively used pastures (23121) & & & 225.55 & 2.29 \\
\hline Extensively used pastures (23122) & 649.31 & 6.59 & 412.41 & 4.19 \\
\hline $\begin{array}{l}\text { Abandoned pastures (degree } \\
\text { overgrowing NDV to } 40 \%)(23123)\end{array}$ & 2.85 & 0.03 & 56.89 & 0.58 \\
\hline $\begin{array}{l}\text { Mosaic of arable land and permanent } \\
\text { grasslands (2415) }\end{array}$ & & & 49.17 & 0.50 \\
\hline
\end{tabular}

tal locality, with the exception of $\mathrm{pH} / \mathrm{CaCl}_{2}, \mathrm{C}_{\text {ox }}$ and $\mathrm{N}_{\text {anorg }}$, on other soil parameters was also statistically significant. Landscape structure changes were identified from historical military maps and historical and present aerial orthophotographs using GIS equipment. Specific landscape structure of the study area represents the relatively stable territory with these following significant changes. The dominant landscape element in all periods was the forest cover. In 1846 outside the forest are identified permanent grasslands and small arable land. In 1949 second largest group of landscape elements were elements of agricultural land (more than $23 \%$ of study area). The main elements are permanent grasslands and arable land. After collectivisation in 1975 the majority of the arable land in Liptovská Teplička was abandoned (Baránková et al., 2011; Špulerová et al., 2013). After succession, overgrowing arable land is now used as extensive meadows and pastures.

\section{Acknowledgements}

The study was supported by VEGA 1/0627/12 Diversity, resiliency and health of ecosystem in different farming systems and polluted territories in anthropogenic land, KEGA 012PU-4/2012 Preparation and realization of research focused on creating teaching aids for education of environmental subjects, KEGA 023UKF-4/2011 Terrain geoecological research as a base for creating of education equipment and VEGA 2/0117/13 Assessment of status and dynamics of habitats using combination of modelling and remote sensing. 


\section{References}

Act. No. 220/2004 on soil protection and agricultural soil using.

Barančíková, G. (1998). The proposal of special classification of agricultural soils of Slovakia from viewpoint of their sensibility to contamination by heavy metals. Rostl. Výroba, 44(3), 117-122.

Baránková, Z., Dobrovodská, M. , Štefunková, D. , Babicová, D. , Moyzeová, M. \& Petrovič F. (2011). Participation of local people on identifying the landscape values and future development in historical agricultural landscapes. Ekológia (Bratislava), 30(2), 216-228. DOI: 10.4149/ekol_2011_02_216.

Beesley, L., Moreno-Jimenez, E. \& Gomez-Eyles J. (2010). Effects of biochar and green waste compost amendments on mobility, bioavailability and toxicity of inorganic and organic contaminants in a multi-element polluted soil. Environ. Pollut., 158, 2282-2287. DOI: 10.1016/j.envpol.2010.02.003.

Bielek, P. (1998). Nitrogen in agricultural soils of Slovakia (in Slovak). Bratislava: VÚPU.

Burns, R.G. (1978). Enzyme activities in soil. Some theoretical and practical considerations. Soil enzymes. New York: Academic Press.

Dick, R.P., Sandor, J.A. \& Eash N.S. (1994). Soil enzyme activities after 1500 years of terrace agriculture in the Colca Valley, Peru. Agric. Ecosyst. Environ., 50, 123-131. DOI: 10.1016/0167-8809(94)90131-7.

Faltan, V. \& Bánovský M. (2008). Changes in land cover in the area of Vyšné Hágy - Starý Smokovec, impacted by the wind calamity in November 2004 (Slovakia). Moravian Geographical Reports, 16(3), 16-26.

Faltan, V., Katina, S., Bánovský, M. \& Pazúrová Z. (2009) The influence of site conditions on the impact of windstorms on forests: the case study of the High Tatras foothills (Slovakia) in 2004. Moravian Geographical Reports, 17(3), 44-52.

Faltan, V., Bánovský, M. \& Blažek M. (2011): Evaluation of land cover changes after extraordinary windstorm by using the land cover metrics: a case study on the high Tatras foothill. Geografie, 116(2), 156-171.

Fazekašová, D., Kotorová, D., Balázs, P., Baranová, B.\& Bobul'ská L. (2011). Spatial variability of physical soil properties in conditions of ecological farming in protected area. Ekológia (Bratislava), 30(1), 1-11. DOI: 10.4149/ ekol_2011_01_1.

Fazekašová, D. (2012). Evaluation of soil quality parametres development in terms of sustainable land use. In S. Curkovic (Ed.), Sustainable development - authoritative and leading edge content for environmental management (pp. 435-458). Rijeka: InTech.

Fazekašová, D., Kotorová, D. \& Bobul'ská L. (2012). Development of biochemical parameters of soil in conditions of sustainable use of soil. Ekológia (Bratislava), 31(2), 238-247. DOI: 0.4149/ekol_2012_02_238.

Fiala, K., Barančíková, G., Brečková, V., Búrik, V., Houšková, B., Chomaničová, A., Kobza, J., Litavec, T., Makovníková, L., Pechová, B. \& Váradiová D. (1999). Partial monitoring system - soil, binding methods (in Slovak). Bratislava: VÚPOP.

Fulajtár, E. (2006). Physical parameters of soil (in Slovak). Bratislava: VÚPOP.

Grejtovský, A. (1991). Influence of soil improvers on enzymatic activity of heavy alluvial soil (in Slovak). Rostl. Výroba 37, 289-295.

Hanzes, L., Britaňák, N., Ilavská, I. \& Lipták L. (2006). Sustainable utilisation of terrace land areas in mountain regions. In Sustainable grassland productivity (Book of abstract) (p. 113). Badajoz: EGF Grassland Science in Europe.

Hanzes, L., Britaňák, N., Ilavská, I. \& Kizeková M. (2011). Restoration of abandoned grassland. In Regional workshop SALVERE project 2011 and Field Days of the European Chapter of the Society for Ecological Restoration (SER Europe) 18-20 May 2011( p. 29). Anhalt University of Applied Science.

Chaziev, F. Kh. (1976). Soil enzyme activity (in Russian). Moskva: Nauka.

Ivanová, M. (2013). Land cover changes of the Zemplinska širava reservoir in the years 1956-2009. Prešov: PU.

Kotorová, D., Šoltysová, B. \& Mati R. (2010). Properties of Fluvisols on the East Slovak Lowland at their different tillage. Pieštany, Michalovce: CVRV.

Kotorová, D. \& Šoltysová B. (2011). Physico-chemical properties of heavy soils. Pieštany: CVRV.

Liška, E., Bajla, J., Candráková, E., Frančák, J., Hrubý, D., Illeš, L., Korenko, M., Nozdrovický, L., Pospišil, R., Špánik, F. \& Žembery J. (2008). General crop production (in Slovak). Nitra: SPU.

Makovníková, J., Barančíková, G., Dlapa, P. \& Dercová K. (2006). Inorganic contaminants in soil ecosystems. Chemické Listy, 100(6), 424-432.

Matúšková, L. \& Vojtáš J. (2005). Guideline for detecting soil contamination (in Slovak). Bratislava: VÚPOP.

Michaeli, E. \& Ivanová M. (2005). Regional geoecological structure of landscape and primary development potential of the Prešov self-governing region. Folia Geographica, 18(8), 116-142. 
Nannipieri, P., Ascher, J., Ceccherini, M.T., Landi, L., Pietramellara, G. \& Renella G. (2003). Microbial diversity and soil function. Eur. J Soil Sci. 54, 655-670. DOI: 0.1046/j.1351-0754.2003.0556.x.

Olah, B. (2003a). Potential for the sustainable land use of the cultural landscape based on its historical use (a model study of the transition zone of the Polana Biosphere Reserve). Ekológia (Bratislava), 22(Suppl. 2), 79-91.

Olah, B. ( 2003b). Land use development of Podpolanie - Management of cultural landscape of the Polana Biosphere Reserve transtion zone (in Slovak). Scientific studies 1/2003/B. Zvolen: Technická univerzita.

Olah, B. (2009). Historical maps and their application in landscape ecological research. Ekológia (Bratislava), 28(2), 143-151.

Pucherová, Z. (2004). Development of land use on the boundary of Zobor and Žitava hilland (on example of selected villages). Nitra: UKF.

Rode, A.A. (1969). Basic science of soil moisture (in Russian). Tom II. Leningrad: Gidrometeorologič. izd.

Sarkar, B., Patra, A.K., Purakayastha, T.J. \& Megharaj M. (2009). Assessment of biological and biochemical indicators in soil under transgenic Bt and non-Bt cotton crop in a sub-tropical environment. Environ. Monit Assess., 156, 595-604. DOI: 10.1007/s10661-008-0508-y.

Sinsabaugh, R.L., Findlay, S., Franchini, P. \& Fischer D. (1997). Enzymatic analysis of riverine bacterioplankton production. Limnol. Oceanogr., 48(1), 29-38.

Solár, V. (2012). Changes of the city of Poprad from the point of view of landscape structure. In H. Svobodová (ed.). Proceedings of $19^{\text {th }}$ International Conference Geography and geoinformatics: Challenge for practise and education (pp. 19-24). Brno.

Šolcová, L. (2012) Development of the landscape with the dispersed settlements in Novobanska stalova area. Nitra: UKF.

Špulerová, J., Dobrovodská, M., Izakovičová, Z., Kenderessy, P., Petrovič, F. \& Štefunková D. (2013): Developing Strategy for protection of traditional agricultural landscapes based on a complex landscape-ecological evaluation (the case study of mountain landscape in Slovakia). Moravian Geographical Reports, 21(4), (in press).

Vilček, J., Hronec, O. \& Bedrna Z. (2005). Environmental pedology (in Slovak). Nitra: SPU, Bratislava: VÚPOP.

Vojteková, J. (2013). Trends in development of mining landscape in the upper Nitra region. Nitra: UKF.

Zaujec, A., Chlpík, J., Nádašský, J., Szombathová, N. \& Tobiašová E. (2009). Pedology and base of geology (in Slovak). Nitra: SPU. 